\title{
Trisomy 8
}

National Cancer Institute

\section{Source}

National Cancer Institute. Trisomy 8. NCI Thesaurus. Code C36396.

A chromosomal abnormality consisting of the presence of a third copy of chromosome 8 in somatic cells. 